Journal of Organometallic Chemistry, 332 (1987) 99-103

Elsevier Sequoia S.A., Lausanne - Printed in The Netherlands

\title{
Convenient procedures for the $\alpha$-metallation of vinylic ethers and thioethers
}

\author{
H.D. Verkruijsse, L. Brandsma, \\ Department of Organometal Mediated Synthesis of the University, Padualaan 8, \\ $3584 \mathrm{CH}$ Utrecht (The Netherlands) \\ and $P$. von R. Schleyer \\ Institut für Organische Chemie der Universität, Henkestrasse 42, D-8520 - Erlangen (F.R.G.) \\ (Received March 11th, 1987)
}

\begin{abstract}
Ethyl vinyl ether $\mathrm{H}_{2} \mathrm{C}=\mathrm{CHOC}_{2} \mathrm{H}_{5}$ and the analogous cyclic vinylic ethers dehydrofuran and 2,3-dihydropyran can be potassiated at $-20^{\circ} \mathrm{C}$ in the $\alpha$-position with a $1 / 1 / 1$ molar mixture of BuLi, t-BuOK and TMEDA in hexane. Methyl vinyl sulfide is potassiated very smoothly by a $1 / 1$ molar mixture of BuLi and $\mathrm{t}-\mathrm{BuOK}$ in THF and hexane at $-80^{\circ} \mathrm{C}$. Subsequent functionalization (some after exchange of potassium for lithium) provided excellent yields.
\end{abstract}

\section{Introduction}

Metallation of vinylic ethers and thioethers $\left(\mathrm{H}_{2} \mathrm{C}=\mathrm{CHXR}, \mathrm{X}=\mathrm{O}\right.$ or $\left.\mathrm{S}\right)$ at the $\alpha$-position has been carried out by use of t-butyllithium in a mixture of tetrahydrofuran and hexane $[1,2]$ or s-butyllithium in tetrahydrofuran with hexamethylphosphoric triamide (HMPT) as co-solvent [5]. t-Butyllithium was also used for the $\alpha$-metallation of the cyclic vinyl ehter, 2,3-dihydrofuran [3], while the six-membered analogue 2,3-dihydropyran was metallated under forcing conditions, with n-butyllithium in THF at $50^{\circ} \mathrm{C}$ [4]. Although the results of subsequent reactions with the intermediates were quite satisfactory, the reaction conditions are less attractive for work on a larger scale. t-Butyllithium is expensive, and the solution in pentane spontaneously ignites upon contact with air. The presence of HMPT in solutions of metallated vinyl sulfides is undesirable if couplings with carbonyl compounds (notably ketones) are to be carried out, since extensive enolate formation may occur [6]. 


\section{Results and discussion}

We reported recently [7] the application of a new super-basic reagent, which can be prepared by simple mixing equimolar quantities of $\mathrm{n}-\mathrm{BuLi}, \mathrm{t}-\mathrm{BuOK}$, $N, N, N^{\prime}, N^{\prime}$-tetramethylethane diamine TMEDA in hexane at $-30^{\circ} \mathrm{C}$ or lower temperatures. With this reagent, which is an almost homogeneous solution, ethyl vinyl ether was completely metallated within $15 \mathrm{~min}$ at temperatures around $-20^{\circ} \mathrm{C}$. Reaction of the (presumed) $\alpha$-potassiated vinyl ether with a higher alkyl bromide (after addition of a sufficient amount of THF) afforded the expected products in excellent yields (see Scheme 1).

After addition of THF and replacement of potassium by lithium * by treatment of anhydrous lithium bromide, the enolisable ketones acetone and cyclopentanone also gave high yields of the carbinols. The metallation of the cyclic vinyl ethers dihydrofuran and dihydropyran took place under similar conditions. Subsequent reaction with dialkyl disulfides (after addition of THF) gave the expected sulfides in more than $90 \%$ yields.<smiles>C1=COCC1</smiles>

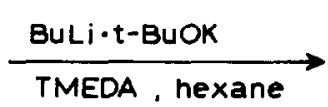<smiles>[Y]C1=CCCO1</smiles><smiles>[R]S[R]([R])([H])C</smiles><smiles>C1=COCCC1</smiles><smiles>[Y]C1=CCCCO1</smiles><smiles>[R5]C1=CCCCO1</smiles>

The metallation of methyl vinyl sulfide was complete within a few seconds at about $-80^{\circ} \mathrm{C}$ with BuLi $\cdot \mathrm{t}-\mathrm{BuOK}[9]$ in THF/hexane mixture. With oxirane, $88 \%$ of the

$$
\begin{aligned}
& \mathrm{H}_{2} \mathrm{C}=\mathrm{CHOC}_{2} \mathrm{H}_{5} \stackrel{\text { BuLi } \cdot \mathrm{t}-\mathrm{BuOK}}{\text { TMEDA, hexane, }-20^{\circ} \mathrm{C}} \mathrm{H}_{2} \mathrm{C}=\mathrm{C}(\mathrm{K}) \mathrm{OC}_{2} \mathrm{H}_{5} \stackrel{\text { LiBr, THF }}{\longrightarrow} \\
& \downarrow \text { THF , } \mathrm{C}_{9} \mathrm{H}_{19} \mathrm{Br} \\
& \mathrm{H}_{2} \mathrm{C}=\left(\mathrm{C}_{9} \mathrm{H}_{19}\right) \mathrm{OC}_{2} \mathrm{H}_{5} \\
& \mathrm{H}_{2} \mathrm{C}=\mathrm{C}\left[\mathrm{C}\left(\mathrm{CH}_{3}\right)_{2} \mathrm{OH}\right] \mathrm{OC}_{2} \mathrm{H}_{5} \\
& \mathrm{H}_{2} \mathrm{C}=\mathrm{C}\left[\left(\mathrm{CH}_{2}\right)_{4} \mathrm{COH}\right] \mathrm{OC}_{2} \mathrm{H}_{5}
\end{aligned}
$$

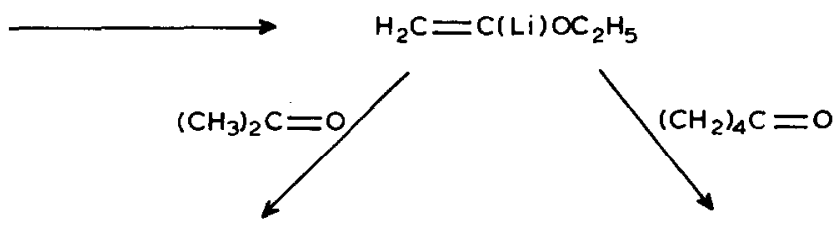

Scheme 1

\footnotetext{
* The use of potassium compounds often gives rise to extensive enolate formation with carbonyl compounds.
} 
coupling product was obtained. Successive addition of anhydrous lithium bromide and acetone gave the carbinol in $84 \%$ yield.

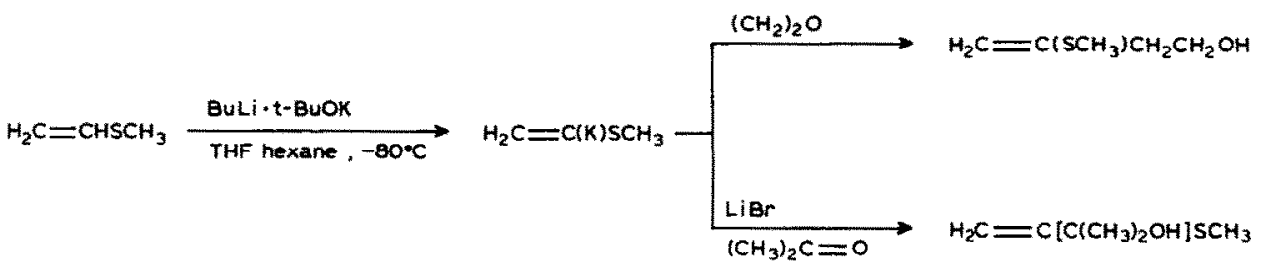

\section{Experimental}

Metallation of ethyl vinyl ether, dihydrofuran and dihydropyran

Potassium t-butoxide $(0.10 \mathrm{~mol})$ and $40 \mathrm{ml}$ of dry hexane or pentane were placed in a 1-1 three-necked, round-bottomed flask. TMEDA $(0.12 \mathrm{~mol}$, dried by distillation from $\mathrm{LiAlH}_{4}$ under reduced pressure) and a solution of $0.10 \mathrm{~mol}$ of butyllithium in $70 \mathrm{ml}$ of hexane were successively added, with cooling below $-30^{\circ} \mathrm{C}$. Freshly distilled ethyl vinyl ether $(0.15 \mathrm{~mol})$, dihydrofuran $(0.12 \mathrm{~mol})$ or dihydropyran $(0.12 \mathrm{~mol})$ were added during a few seconds at $-40^{\circ} \mathrm{C}$. The mixture was then stirred for $15 \mathrm{~min}$ at $-20^{\circ} \mathrm{C}$ and an additional $5 \mathrm{~min}$ at $-10^{\circ} \mathrm{C}$.

\section{Metallation of methyl vinyl sulfide}

A solution of $0.10 \mathrm{~mol}$ of potassium t-butoxide in $70 \mathrm{ml}$ of THF was added during $5 \mathrm{~min}$ to a solution of $0.10 \mathrm{~mol}$ of butyllithium in $70 \mathrm{ml}$ of hexane, the temperature of the mixture being kept between -90 and $-95^{\circ} \mathrm{C}$ by efficient cooling with liquid nitrogen. Methyl vinyl sulfide $(0.10 \mathrm{~mol}$, for the preparation see ref. 8) was then added during $5 \mathrm{~min}$ at $-90^{\circ} \mathrm{C}$. A light-yellow suspension was formed almost immediately. After an additional 5 min (at $-80^{\circ} \mathrm{C}$ ) the solution was used for the reactions described below.

\section{Reaction of potassiated ethyl vinyl ether with nonyl bromide}

THF $(70 \mathrm{ml})$ and then $0.09 \mathrm{~mol}$ of nonyl bromide were added to a solution of potassiated ethyl vinyl ether in hexane. The cooling bath was removed and the temperature allowed to rise. Stirring was continued at $20^{\circ} \mathrm{C}$ for an additional 30 $\min$, then water $(200 \mathrm{ml})$ was added. After three extractions with diethyl ether, the combined organic solutions were washed with saturated aqueous $\mathrm{NH}_{4} \mathrm{Cl}$ and then dried over $\mathrm{MgSO}_{4}$. After concentration in vacuo, the product was distilled. $\mathrm{H}_{2} \mathrm{C}=\mathrm{C}\left(\mathrm{C}_{9} \mathrm{H}_{19}\right) \mathrm{OC}_{2} \mathrm{H}_{5}$, b.p. $107^{\circ} \mathrm{C} / 15 \mathrm{mmHg}, n_{\mathrm{D}}^{18} 1.4364$ was obtained in $86 \%$ yield.

Reaction of $\alpha$-lithio-vinyl ethyl ether with acetone and cyclopentanone

THF $(60 \mathrm{ml})$ was added to the solution of potassiated vinyl ethyl ether, and a solution of $0.13 \mathrm{~mol}$ of anhydrous lithium bromide in $40 \mathrm{ml}$ of THF was then added at $-10^{\circ} \mathrm{C}$. (The commercial anhydrous salt was first heated for $30 \mathrm{~min}$ at $150^{\circ} \mathrm{C}$ under $15 \mathrm{mmHg}$ pressure in order to remove traces of water.) The suspension was cooled to $-60^{\circ} \mathrm{C}$ and acetone or cyclopentanone $(0.10 \mathrm{~mol})$ was added dropwise during $5 \mathrm{~min}$ as the temperature was kept below $-40^{\circ} \mathrm{C}$, and $4 \mathrm{~min}$ later $100 \mathrm{ml}$ of 
saturated aqueous $\mathrm{NH}_{4} \mathrm{Cl}$ was added with vigorous stirring. After separation of the layers, three extractions with diethyl ether were carried out. The combined organic solutions were freed from t-butylalcohol and TMEDA by shaking with saturated aqueous $\mathrm{NH}_{4} \mathrm{Cl}$ (4 times). The solutions were dried over $\mathrm{MgSO}_{4}$ and subsequently concentrated in vacuo. Distillation gave the carbinol $\mathrm{H}_{2} \mathrm{C}=\mathrm{C}\left(\mathrm{OC}_{2} \mathrm{H}_{5}\right) \mathrm{C}\left(\mathrm{CH}_{3}\right)_{2} \mathrm{OH}$, b.p. $45^{\circ} \mathrm{C} / 12 \mathrm{mmHg}, n_{\mathrm{D}}^{20} 1.4306$, in $82 \%$ yield and the related cyclopentanone carbinol, b.p. $75^{\circ} \mathrm{C} / 15 \mathrm{mmHg}$ in $84 \%$ yield. The latter compound solidified slowly upon standing at room temperature.

\section{Thioalkylation of potassiated dihydrofuran and dihydropyran}

THF $(50 \mathrm{ml})$ and diethyl ether $(50 \mathrm{ml})$ was added to the solution of the potassiated cyclic vinyl ether, and the solution then cooled to $-50^{\circ} \mathrm{C}$. Dimethyl disulfide or diethyl disulfide $(0.12 \mathrm{~mol})$ was added in one portion, and the temperature then allowed to rise. After an additional $10 \mathrm{~min}, 100 \mathrm{ml}$ of water was added with vigorous stirring. The layers were separated and the aqueous layer extracted three times with diethyl ether. The combined organic solutions were washed five times with saturated aqueous $\mathrm{NH}_{4} \mathrm{Cl}$ and then dried over $\mathrm{MgSO}_{4}$. After evaporation of the solvent, the remaining liquid was distilled.

Dihydrofuranyl ethyl sulfide, b.p. $65^{\circ} \mathrm{C} / 12 \mathrm{mmHg}, n_{\mathrm{D}}^{20} 1.5071$, and dihydropyranyl methyl sulfide, b.p. $70^{\circ} \mathrm{C} / 12 \mathrm{mmHg}, n_{\mathrm{D}}^{20} 1.5179$, were obtained in $90-94 \%$ yields.

Reaction of potassiated methyl vinyl sulfide with oxirane

Oxirane $(0.14 \mathrm{~mol})$ was added at $-60^{\circ} \mathrm{C}$ to the suspension of potassiated methyl vinyl sulfide. The cooling bath was removed, and the temperature allowed to rise to $-20^{\circ} \mathrm{C}$. Intermittent cooling was used to keep the exothermic reaction under control. After an additional $15 \mathrm{~min}\left(\right.$ at $-20^{\circ} \mathrm{C}$ ) water $(50 \mathrm{ml}$ ) was added. After separation of the layers, three extractions with diethyl ether werc carried out. The unwashed extracts were dried over $\mathrm{MgSO}_{4}$ and subsequently concentrated under reduced pressure. Distillation through a short column gave $\mathrm{H}_{2} \mathrm{C}=\mathrm{C}\left(\mathrm{SCH}_{3}\right) \mathrm{CH}_{2}$ $\mathrm{CH}_{2} \mathrm{OH}$, b.p. $87^{\circ} \mathrm{C} / 12 \mathrm{mmHg}, n_{\mathrm{D}}^{20} 1.5133$, in $88 \%$ yield.

\section{Reaction of lithiated methyl vinyl sulfide with acetone}

To the suspension of potassiated methyl vinyl sulfide was added at $-80^{\circ} \mathrm{C}$ a solution of $0.14 \mathrm{~mol}$ of anhydrous lithium bromide in $40 \mathrm{ml}$ of THF (for drying of $\mathrm{LiBr}$ vide infra). After an additional $10 \mathrm{~min}$, acetone $(0.10 \mathrm{~mol})$ was added during 1 min at $-70^{\circ} \mathrm{C}$, and then, after a $1 \mathrm{~min}$ interval, $100 \mathrm{ml}$ of water. Work up as described for the reaction with oxirane gave the carbinol $\mathrm{H}_{2} \mathrm{C}=\mathrm{C}\left[\mathrm{C}\left(\mathrm{CH}_{3}\right)_{2} \mathrm{OH}_{\mathrm{SCH}_{3}}\right.$, b.p. $70^{\circ} \mathrm{C} / 12 \mathrm{mmHg}, n_{\mathrm{D}}^{20} 1.5012$, in $84 \%$ yield.

\section{References}

1 J.E. Baldwin, G.A. Hofle and O.W. Lever Jr., J. Amer. Chem. Soc., 96 (1974) 7125.

2 E.M. Dexheimer and L. Spialter, J. Organomet. Chem., 107 (1976) 229.

3 R.K. Boeckman, Jr. and K.J. Bruza, Tetrahedron Lett., (1977) 4187.

4 O. Riobe, A. Lebouc and J. Delaunay, Compt. Rend. Acad. Sci., Paris. Ser. C, 284 (1977) 281.

5 K. Oshima, K. Shimoji, H. Takahashi, H. Yamamoto and H. Nozaki, J. Amer. Chem. Soc., 95 (1973) 2694. 
6 E. Juaristi and E.L. Eliel, Tetrahedron Lett., (1977) 543.

7 (a) C. Schade, W. Bauer and P. von R. Schleyer, J. Organomet. Chem., 295 (1985) C25, (b) L. Brandsma, C. Schade, H.D. Verkruijsse and P. von R. Schleyer, J. Chem. Soc., Chem. Commun., (1986) 260.

8 L. Brandsma and H.D. Verkruijsse, Preparative Polar Organometallic Chemistry, Vol. 1, SpringerVerlag, Berlin, 1986.

9 (a) L. Lochmann, J. Posposol and D. Lim, Tetrahedron Lett., (1966) 257; (b) M. Schlosser, J. Organomet. Chem., 8 (1967) 9. 